\title{
The Asiatic garden beetle Maladera castanea (Arrow 1913) (Coleoptera: Scarabaeidae) ${ }^{1}$
}

Paul E. Skelley ${ }^{2}$

\section{Introduction}

The Asiatic garden beetle, Maladera castanea (Arrow), has been a pest in the northeastern United States since the 1920s. Generally not as abundant or damaging as the Japanese beetle (Popillia japonica Newman), the Asiatic garden beetle is occasionally numerous enough to cause damage to turf, gardens and field crops, as well as simply being a nuisance. The discovery of the Asiatic garden beetle in Florida was not unexpected. This is the first report of this pest beetle in the lower southeastern U.S. coastal plain.

\section{Distribution}

The Asiatic garden beetle, native to China and Japan, became established in New Jersey around 1921 (Hawley and Hallock 1936, Tashiro 1987) and has slowly expanded its range in the Northeast. Tashiro (1987) presented data showing that it occurs in much of New England, with a localized infestation in South Carolina. Evans (2002) listed it as occurring in Georgia, but did not provide information on date of capture. The University of Georgia Collection of Arthropods has specimens from central Georgia collected in 1978 and 1991, with more recent collections in several northern counties in the early 2000s (J. McHugh and R. Hoebeke, pers. comm.). In the past few years, additional new records have been published: for Canada 2003 in Quebec (Chantal 2003) and 2009 in Nova Scotia (Cutler and Rogers 2009); for the United States 2006 in Indiana (Richmond 2010) and Illinois (Scott 2006; 2009 reported by NAPIS 2012), 2007 in Missouri (NAPIS 2012), 2008 in

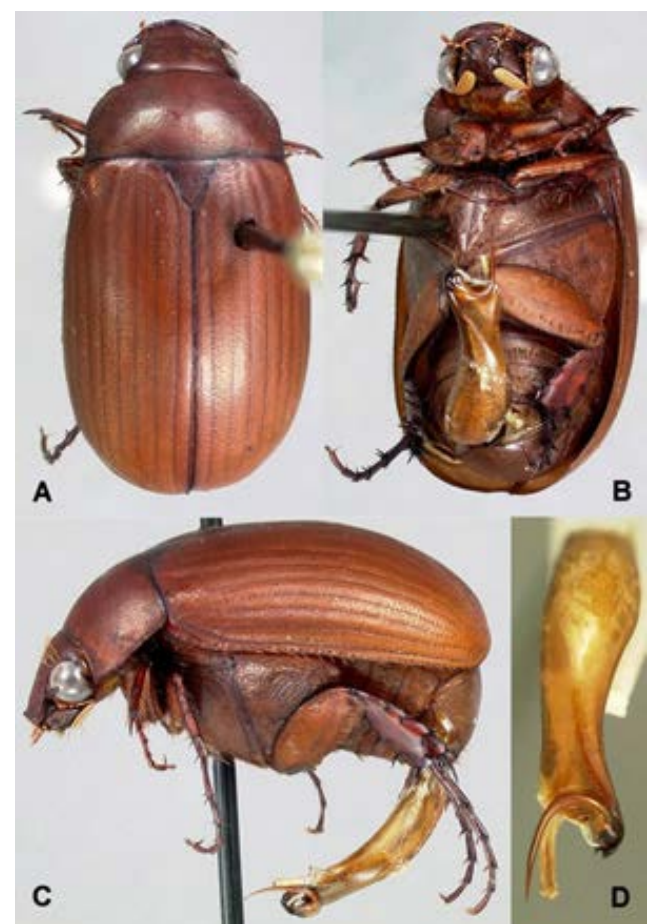

Figure 1. Adult Maladera castanea (Arrow), Asiatic garden beetle: A) dorsal, B) ventral, C) lateral and D) male genitalia. Credits: Paul Skelley, Florida Department of Agriculture and Consumer Services.

Kansas (NAPIS 2012), and 2008 in Alabama (Held and Ray 2009).

There appears to be a rapid dispersal westward, but not southward. With the beetles being in central Georgia since 1978, we would have expected it in Florida much earlier. However, the first known collection of the Asiatic

1. This document is EENY 554, one of a series of the Entomology and Nematology Department, Florida Cooperative Extension Service, Institute of Food and Agricultural Sciences, University of Florida. Original publication date April 2013. Visit the EDIS website at http://edis.ifas.ufl.edu.

2. Paul E. Skelley, Florida Department of Agriculture and Consumer Services, Division of Plant Industry and affiliate faculty Entomology and Nematology Department, Institute of Food and Agricultural Sciences, University of Florida, Gainesville, FL 32611.

The Institute of Food and Agricultural Sciences (IFAS) is an Equal Opportunity Institution authorized to provide research, educational information and other services only to individuals and institutions that function with non-discrimination with respect to race, creed, color, religion, age, disability, sex, sexual orientation, marital status, national origin, political opinions or affiliations. U.S. Department of Agriculture, Cooperative Extension Service, University of Florida, IFAS, Florida A\&M University Cooperative Extension Program, and Boards of County Commissioners Cooperating. Nick T. Place , Dean 
garden beetle in Florida was in the Black Creek Ravines Conservation Area, Middleburg, Clay Co., $\left(30.08099^{\circ} \mathrm{N}\right.$, $81.84125^{\circ} \mathrm{W}$ ), on 6 May 2012, by J. Garrison at light (three specimens). This is a remote natural area that is not near any businesses importing potted plants or turf. The initial collection was soon followed by a collection at the 7600 block of Beaver Street of Jacksonville, Duval Co., on 11 May 2012, by G. Durrance (two specimens). These distant localities and its occurrence in a natural area indicate that the Asiatic garden beetle is established in northern Florida.

\section{Habits}

Adults feed on leaves and flowers. When infestations are heavy, they can eat leaves to the midrib. Adults are known to feed on over 100 different plants, including leaves of boxelder, viburnum, peach, cherry, strawberry, carrot, beet, eggplant, pepper, turnip and flowers such as aster, chrysanthemum, roses and goldenrod. Larvae feed on roots of various plants, appearing to prefer overgrown weedy areas to well-maintained, short grassy areas. While considered to be a minor pest, larval feeding is less notable than that of adults, except when in large numbers. This is partly because larvae burrow deeper than many other grubs (Tashiro 1987), where they may feed on more peripheral roots and not the main root ball. However, larvae are known to cause problems in ornamentals, turf, gardens, sweet potatoes, soybeans, corn and other field crops. Cutler and Rogers (2009) discussed larvae causing damage to blueberries.

In the northern U.S., adults emerge in the summer from the end of June through October and are univoltine (Tashiro 1987). Conditions for their emergence predict an earlier emergence in the South and that they could have more than one generation per year (Held and Ray 2009). The new Florida records confirm their earlier emergence. It is not known whether they are univoltine or bivoltine in Florida.

\section{Detection}

Adults are active at night and can be found feeding on foliage and flowers. Adults are attracted to light, and can easily be monitored with light traps. Larvae must be dug from the soil or from potted plants.

\section{Management}

Some research has been done specifically on controlling the Asiatic garden beetle (Koppenhöfer and Fuzy 2003). Other references list various control options (Shetlar and Niemczyk 1999). Recommended controls for white grubs and foliar feeding insects change from time to time and depend on the plant being damaged. In Florida, consult your county Cooperative Extension Office for the most recent control recommendations for the plants or crops in question.

\section{Acknowledgments}

I thank Jamie Garrison, Middleburg, FL, for recognizing the first Florida specimens. Arthur Evans (Richmond, VA), Bruce Gill (Canadian Food Inspection Agency, Entomology Unit, Ottawa, Canada), and Paul Lago (Department of Biology, University of Mississippi, MS) are thanked for insight into the literature on the Asiatic garden beetle, as well as discussion of the beetle in their regions; Rick Hoebeke and Joseph McHugh for providing Georgia records from the University of Georgia Collection of Arthropods, Athens, Georgia. Gary Steck, Susan Halbert, Mike Thomas and Wayne Dixon (Florida Department of Agriculture and Consumer Services, Division of Plant Industry, Gainesville, FL) provided prerelease reviews of this article. This is Florida Department of Agriculture and Consumer Services, Entomology Contribution Number 1229.

\section{Selected References}

Chantal C. 2003. Maladera castanea (Arrow, 1903). Fabreries 28: 27.

Cutler GC, Rogers REL. 1990. New record of the Asiatic garden beetle, Maladera castanea (Arrow), in Atlantic Canada. Journal of the Entomological Society of Ontario 140: $40-45$.

Evans A. 2002. III. Melolonthinae Samouelle 1819. pp. 51-60. In: R.H. Arnett, Jr., M.C. Thomas, P.E. Skelley, and J.H. Frank (eds). American Beetles. Volume 2. CRC Press LLC, Boca Raton, FL. 861 pp.

Harpootlian P. 2001. Scarab beetles (Coleoptera: Scarabaeidae) of South Carolina. Biota of South Carolina 2: 1-157.

Hawley IM, Hallock HC. 1936. Life history and control of the Asiatic garden beetle. USDA Circular 246: 1-20. [Revision of 1932 issue by H.C. Hallock of same title.] 
Held DW, Ray CH. 2009. Asiatic garden beetle Maladera castanea (Coleoptera: Scarabaeidae) grubs found in damaged turf in Alabama. Florida Entomologist 92: 670-672.

Koppenhöfer AM, Fuzy EM. 2003. Biological and chemical control of the Asiatic garden beetle, Maladera castanea (Coleoptera: Scarabaeidae). Journal of Economic Entomology 96: 1076-1082.

NAPIS [National Agriculture Pest Information System]. 2012. Asiatic garden beetle distribution. (4 April 2013).

Richmond D. 2010 (revised). New white grub pests of Indiana. Landscape \& Ornamentals. Purdue University, Department of Entomology. Purdue Extension E-259-W: 1-3. (4 April 2013).

Ritcher PO. 1966. White grubs and their allies, a study of North American scarabaeoid larvae. Oregon State Monographs, Studies in Entomology, Number 4: 1-219.

Scott S. 2006. Maladera castanea. BugGuide posting, photos \#71527 and \#71528. and (4 April 2013).

Shetlar D, Niemczyk HD. 1999. Asiatic garden beetle. DJS-HDN Turfgrass FactSheet. 5 p. (4 April 2013).

Tashiro H. 1987. Scarabaeid pests: Subfamily Melolonthinae, Asiatic garden beetle. pp. 156-162. In: H. Tashiro. Turfgrass Insects of the United States and Canada. Ithaca, NY: Cornell University. 391 pp. 